\title{
A lifeworld interpretation of tinnitus
}

\section{Helen Pryce* 1 \& Rachel Shaw 2}

${ }^{*}$ corresponding author

1 Audiology Department,

School of Life and Health Sciences,

Aston University, Aston triangle, Birmingham B4 7ET, UK.

h.pryce-cazalet@aston.ac.uk

01212044131

2. Psychology Department,

School of Life and Health Sciences,

Aston University, Aston Triangle, Birmingham B4 7ET, UK.

Keywords:

Tinnitus

Life-world

Qualitative

Embodiment

Invisible

Word count: 2142 


\section{A lifeworld interpretation of tinnitus}

\section{Abstract}

Lifeworld-led care provides a route through which research and practice can navigate the 'biopsychosocial' allowing us to overcome the shortfalls of the medical model and enabling us to prioritise humanity in the care of people living with tinnitus. In this article we sought to explore qualitative descriptions of life with tinnitus. We aimed to address the question 'what it is like to live with tinnitus?' In doing so we examined qualitative studies and provide suggestions about key themes that seem consistent. This is a narrative, thematic overview of the way lifeworld has been conceptualized and explored in tinnitus research.

\section{Background}

Tinnitus challenges biomedical understandings of health and illness. Whilst in some cases it is a symptom of a pathology and a target for medical treatment, chronic tinnitus is a subjective condition, experienced through the lens of an individual life. What is more it is a heterogeneous experience, affecting a huge proportion of humanity (estimates vary from $3 \%$ to $30 \%$, increasing with age $)^{1}$. Alongside this heterogeneity there is variation in healthcare responses to tinnitus with a wide variation in care provided ${ }^{2}$. Current UK Good Practice Guidance for commissioning tinnitus services recommends treating tinnitus related distress via information and education, hearing aids, counselling and psychological support, relaxation therapy, cognitive behavioural therapy, sleep management and sound enrichment. The use of antidepressants, anxiolytic and night sedation may also be required in some cases ${ }^{3}$. Recent development of a patient decision aid has provided a resource for clinicians and patients to enable shared decision making in tinnitus care ${ }^{4}$.

Without clear mechanistic process or pathology underpinning the tinnitus perception, the concept of a 'cure' remains ambiguous. There have been forays into surgery ${ }^{5}$ and medical devices ${ }^{6}$ but with no long term reduction in tinnitus perception.

The British Tinnitus Association has focused their research strategies on finding a cure ${ }^{7}$, cure remains a preference for people affected by tinnitus. ${ }^{8}$ Yet consistently the most effective interventions for tinnitus target coping rather than cure ${ }^{9}$. The switch between symptom eradication 
and building coping mechanisms is one that challenges scripts used by clinicians ${ }^{10}$. Clinicians must communicate uncertainty about causal factors, while offering evidence based options for care that rely on psychological adaptation ${ }^{10}$. This is a common experience with invisible conditions and subjective health experiences ${ }^{11}$. People presenting for help with complex symptoms create feelings of frustration, inadequacy and powerlessness in clinicians ${ }^{11}$. In turn this leads to barriers in communication and reduced shared decision making ${ }^{10}$.

\section{Making tinnitus 'true'}

We have a limited understanding of tinnitus perception from the view of the perceiver. Instead, to conceptualise individual subjective perception, clinicians and researchers have employed objective measures. Tinnitus pitch \& loudness matching tests are used, and more recently fMRI studies have provided proxy measures of brain activity ${ }^{12}$. In pitch and loudness matching tests patients indicate when a clinician or researcher has identified a sound that shares some qualities with the sound that they are perceiving at that time ${ }^{12}$. Thereby turning the tinnitus into objective fact e.g. an observable measurement. This risks missing the opportunity to explore the subjective and meaningful aspects of the tinnitus. It risks communicating to the patient that there is a separation between valid, measurable signs and their experienced symptoms. Furthermore, it dehumanizes people with tinnitus by reducing their experience to mechanics ${ }^{13}$. As a result there is a disconnect between the clinical view, based on biomedical markers of tinnitus, and the 'insider' perspective ${ }^{13}$. Understanding the 'insider' view and the nature of 'insiderness' for people with tinnitus is important in humanizing healthcare ${ }^{13}$. For example, people with tinnitus may seek help only to be told 'there's no cure' or worse, 'there's nothing we can do'. These remarks may strictly speaking be true in that a persistent symptom with no obvious pathophysiology does not lend itself to medical treatment. Yet the consequences of these remarks are that people feel dismissed ${ }^{8}$. What is more there are treatments that are effective at reducing the distress associated with the perception. Cognitive behavioural therapy, mindfulness, and acceptance and commitment therapy have demonstrably reduced tinnitus distress ${ }^{9,14}$. These approaches depend on individualised reinterpretation of bodily signs (tinnitus) and symptoms (bodily markers of stress). There is 
tremendous social pressure on validating tinnitus as an externally 'true' experience for researchers, clinicians and patients. But this is social pressure. It reflects the hierarchy of illness that our culture condones ${ }^{15}$.

Quantifying the tinnitus helps validate the 'sick role' ${ }^{16}$ which is socially sanctioned only if symptoms are seen as pointing to a valid illness. The lack of visibility compromises this socially sanctioned role as does the questionable element of mental, rather than physical, illness. It is risky for those with tinnitus to honestly describe their psychological suffering. There is a risk that the patient experience is pushed to one side in favour of statistically driven generalizations about population average mechanisms and treatments ${ }^{17}$.

\section{The importance of understanding the 'lifeworld'}

We know very little about what it is really like to live with tinnitus. Interpretivism proposes that dualism is inherently meaningless within the human realm ${ }^{18}$ where experience is regarded as unique, and constructed, based on individual learning, cultural and psychological perspectives. The perception is inseparable from the perceiver ${ }^{19}$.

There is a growing understanding that 'lifeworld' contrasts with the medical world view ${ }^{20}$. Lifeworld is the descriptive term for the individualised world view and individualised embodied sense. It is inherently subjective and unique. It is also infused with important meanings and clues about what matters to the individual. Lifeworld is a concept attributed to Edmund Husserl (1859-1938). It is 'the construct of a universal, ultimately functioning, subjectivity' ${ }^{21}$. This distinguishes lifeworld from the notion of scientific objectivity and places lifeworld as the fundamental starting point for all enquiry within the human realm.

Surprisingly, given the inherently subjective nature of tinnitus, there have only recently been a handful of studies which acknowledge the lifeworld of tinnitus. Such studies have captured the contrasts between the medical model and the concept of the lifeworld during clinical encounters and help-seeking ${ }^{10 .}$ There are in depth descriptions of adjustments in thinking as coping changes 
and matures in the presence of tinnitus ${ }^{22}$. Patient preferences for treatments have been modelled

${ }^{8}$. Dauman et al 2017 aimed to capture and describe 'tinnitus induced disablement' and provide in depth insights into the lived experience of tinnitus ${ }^{23}$. This growing body of qualitative research, using a variety of methods from individual and focus group interviews to ethnographic observations, has informed our understanding of not only what the tinnitus experience is but how and why tinnitus is experienced in particular ways.

Qualitative research offers important new insights in both emancipating the patient voice and bringing the patient view into research discourse. It lends new insight into the inherent 'felt sense' of tinnitus ${ }^{24}$.

\section{The embodiment of tinnitus}

The concept of 'felt sense' is intrinsically linked to the notion of 'feeling tone' ${ }^{20}$. These terms encapsulate the way that a feeling is experienced not simply as a separate and discrete emotion, but one that permeates the lifeworld. Any situation is infused with 'feeling tone' which may or may not be articulated. This may provide helpful insight into the mechanisms behind coping processes offering a rich new understanding of how a perception is experienced and what mechanisms are important in determining how it is experienced. In order to explore tinnitus it is vital that we understand the experience of the perceiver rather than extricate the perception from the perceiver.

A simple PubMed search for 'tinnitus and treatment' yields 7665 hits. The literature utilizing qualitative methods is sparse. Of 65 results containing qualitative aspects, all but 14 articles are using 'qualitative' to mean a description of the tinnitus sound heard. There are very few articles exploring patient experience beyond this. Of those that exist, two elicit views of treatment ${ }^{25}$, one explores general attitudes to leisure noise ${ }^{26}$. One explores trauma distress and adaptation in a related condition for which tinnitus is a symptom with a focus group interview ${ }^{27}$. Watts et al (2018) used qualitative methods to list the problems associated with tinnitus ${ }^{28}$. Patient preferences for treatments and outcomes have also been examined ${ }^{8}$. These provide useful background and 
information but do not address the lifeworld perspective, in the sense of telling us what living with tinnitus is like.

To address the lifeworld perspective we have explored further 9 remaining studies that focus on what it is like to live with tinnitus. The studies included used qualitative methodologies including ethnography, grounded theory and phenomenology to generate new understandings and insights into the lifeworld of tinnitus. Whilst not a systematic review, this narrative review synthesises the rich data generated in explorations of the lifeworld of tinnitus. We have carried out an interpretative synthesis to generate a set of themes which summarise the patterns of lifeworld experience that are present in these published accounts. This was based on exploring the findings for commonalities in the presented categories and themes (from the grounded theory informed studies) and the descriptive themes from the ethnographic and phenomenological studies. All themes were listed and grouped into common categories following the procedures of thematic synthesis ${ }^{29}$. This was an interpretative synthesis which generated a set of new themes representing the included studies. Finally the researchers applied summary labels to the themes. Table 1 summarises characteristics of the studies. 
Table 1: Characteristics of papers reviewed

\begin{tabular}{|c|c|c|c|c|}
\hline Paper authors and title & $\begin{array}{l}\text { Methodological } \\
\text { framework and } \\
\text { purpose }\end{array}$ & $\begin{array}{l}\text { Data collection } \\
\text { methods }\end{array}$ & $\begin{array}{l}\text { Data analysis } \\
\text { methods }\end{array}$ & Contribution summary \\
\hline $\begin{array}{l}\text { Pryce \& Chilvers, } 2018 . \\
\text { Losing silence, gaining } \\
\text { acceptance: the role of } \\
\text { thoughts in adult patients } \\
\text { with subjective tinnitus. }{ }^{22}\end{array}$ & $\begin{array}{l}\text { The study explored the } \\
\text { thinking patterns } \\
\text { described by clinical } \\
\text { help-seeking } \\
\text { participants. }\end{array}$ & $\begin{array}{l}13 \text { people with } \\
\text { tinnitus } \\
\text { participated in } \\
\text { semi structured } \\
\text { interviews }\end{array}$ & $\begin{array}{l}\text { Data were analysed } \\
\text { in line with } \\
\text { grounded theory } \\
\text { methods. }\end{array}$ & $\begin{array}{l}\text { Patterns of thinking associated with distressing tinnitus } \\
\text { were identified. The core category was 'sense-making' and } \\
\text { there were } 8 \text { themes around this. }\end{array}$ \\
\hline $\begin{array}{l}\text { Thompson, Pryce, El } \\
\text { Refaie.2011. Group or } \\
\text { individual tinnitus therapy: } \\
\text { what matters to } \\
\text { participants? }{ }^{22}\end{array}$ & $\begin{array}{l}\text { A grounded theory } \\
\text { approach was taken to } \\
\text { explore the experiences } \\
\text { through which individual } \\
\text { or group therapy } \\
\text { supported coping. }\end{array}$ & $\begin{array}{l}8 \text { clinical help- } \\
\text { seekers } \\
\text { participated in } \\
\text { open ended } \\
\text { interviews }\end{array}$ & $\begin{array}{l}\text { Constant } \\
\text { comparison of data } \\
\text { categories }\end{array}$ & $\begin{array}{l}\text { Experiences of tinnitus improved by mechanisms of } \\
\text { information and social comparison }\end{array}$ \\
\hline
\end{tabular}




\begin{tabular}{|c|c|c|c|c|}
\hline $\begin{array}{l}\text { Dauman, Erlandson, } \\
\text { Albaracin and Dauman. } \\
\text { 2017. Exploring Tinnitus- } \\
\text { Induced Disablement by } \\
\text { Persistent Frustration in } \\
\text { Aging Individuals: A } \\
\text { Grounded Theory Study. }\end{array}$ & $\begin{array}{l}\text { A grounded theory based } \\
\text { study which sought to } \\
\text { enlighten variability in } \\
\text { tinnitus-induced } \\
\text { disablement using a } \\
\text { qualitative approach }\end{array}$ & $\begin{array}{l}12 \text { people with } \\
\text { tinnitus } \\
\text { participated in } 3 \\
\text { interviews each } \\
\text { exploring } \\
\text { 'tinnitus induced } \\
\text { disablement'. }\end{array}$ & $\begin{array}{l}\text { Data were analysed } \\
\text { following grounded } \\
\text { theory methods }\end{array}$ & $\begin{array}{l}4 \text { main themes: } \\
\text { Tinnitus as a persistent frustration, losing body ownership, } \\
\text { lacking perspectives and persevering through difficulties }\end{array}$ \\
\hline $\begin{array}{l}\text { Adams, Verrier, Walsh } \\
\text { and Lind. } 2010 \text {. Adults' } \\
\text { perceptions of their } \\
\text { tinnitus and a tinnitus } \\
\text { information service. }{ }^{30}\end{array}$ & $\begin{array}{l}\text { Study aiming to identify } \\
\text { key motivations for } \\
\text { adults seeking tinnitus } \\
\text { advice, how those } \\
\text { services are perceived } \\
\text { and insight into help- } \\
\text { seeking behaviour. } \\
\text { Grounded theory } \\
\text { methodology } \\
\text { underpinned data }\end{array}$ & $\begin{array}{l}\text { Semi structured } \\
\text { interviews with } \\
13 \text { participants } \\
\text { informed by } \\
\text { grounded theory. }\end{array}$ & $\begin{array}{l}\text { Category } \\
\text { development and } \\
\text { description. }\end{array}$ & $\begin{array}{l}\text { Descriptive categories were 'empowerment through } \\
\text { education' and 'If you can't cure me l'll cope' }\end{array}$ \\
\hline
\end{tabular}




\begin{tabular}{|c|c|c|c|c|}
\hline & $\begin{array}{l}\text { gathering and analysis } \\
\text { methods. }\end{array}$ & & & \\
\hline $\begin{array}{l}\text { Wheeler and Hopwood } \\
\text { 2015. Tinnitus: a } \\
\text { Deafhearing } \\
\text { phenomenon }{ }^{31}\end{array}$ & $\begin{array}{l}\text { Auto ethnography } \\
\text { providing descriptive } \\
\text { account of the authors' } \\
\text { experiences of tinnitus } \\
\text { with and without } \\
\text { profound deafness. }\end{array}$ & $\begin{array}{l}\text { Author and her } \\
\text { cousin describe } \\
\text { their experience } \\
\text { with tinnitus from } \\
\text { a Deaf and } \\
\text { hearing } \\
\text { perspective }\end{array}$ & $\begin{array}{l}\text { This takes the form } \\
\text { of a brief, } \\
\text { descriptive set of } \\
\text { postings. }\end{array}$ & $\begin{array}{l}\text { A description of impacts of tinnitus from a Deaf and } \\
\text { hearing perspective. }\end{array}$ \\
\hline $\begin{array}{l}\text { Greenberg and Leigh } \\
2018 \text {. Loss meaning } \\
\text { making and reconstruction } \\
\text { of narratives in adults } \\
\text { enduring tinnitus } \\
\text { exacerbated by exposure } \\
\text { to sound }\end{array}$ & $\begin{array}{l}\text { A qualitative survey of } \\
\text { written responses to } 3 \\
\text { open -ended questions. }\end{array}$ & $\begin{array}{l}418 \text { volunteer } \\
\text { participants from } \\
\text { English speaking } \\
\text { world responded } \\
\text { to } 3 \text { open ended } \\
\text { questions }\end{array}$ & $\begin{array}{l}\text { Conducted thematic } \\
\text { analysis of } 418 \\
\text { unique responses }\end{array}$ & $\begin{array}{l}5 \text { themes were identified: loss, psychological impact, } \\
\text { inadequate understanding, crisis of meaning, and } \\
\text { solutions. }\end{array}$ \\
\hline
\end{tabular}




\begin{tabular}{|c|c|c|c|c|}
\hline $\begin{array}{l}\text { Marks, Smith \& McKenna } \\
2019 . \\
\text { Living with tinnitus and the } \\
\text { healthcare journey: an } \\
\text { interpretive } \\
\text { phenomenological } \\
\text { analysis. }{ }^{33}\end{array}$ & $\begin{array}{l}\text { An IPA study with a sub } \\
\text { sample participating in a } \\
\text { randomized controlled } \\
\text { trial. }\end{array}$ & $\begin{array}{l}\text { A sub sample of } \\
9 \text { participants } \\
\text { under going a } \\
\text { randomized } \\
\text { controlled trial } \\
\text { into Mindfulness } \\
\text { Based Cognitive } \\
\text { behavioural } \\
\text { therapy } \\
\text { undertook } \\
\text { interviews }\end{array}$ & IPA analysis & $\begin{array}{l}\text { Descriptions of the distress inherent in the tinnitus } \\
\text { experience and the role of clinical encounters in increasing } \\
\text { distress. }\end{array}$ \\
\hline $\begin{array}{l}\text { Andersson and Edvinsson } \\
2008 . \\
\text { Mixed feelings about living } \\
\text { with tinnitus: a qualitative } \\
\text { study. }{ }^{34}\end{array}$ & $\begin{array}{l}\text { Grounded theory } \\
\text { informed study } \\
\text { Purpose; to explore } \\
\text { patients' views of tinnitus } \\
\text { and their treatment }\end{array}$ & $\begin{array}{l}7 \text { purposefully } \\
\text { sampled } \\
\text { participants } \\
\text { participated in } \\
\text { semi-structured } \\
\text { interviews }\end{array}$ & $\begin{array}{l}\text { Based on grounded } \\
\text { theory } \\
\text { categorization } \\
\text { methods }\end{array}$ & $\begin{array}{l}3 \text { main categories labelled: } \\
\text { Consequences, Treatment experiences and tinnitus } \\
\text { identity }\end{array}$ \\
\hline
\end{tabular}




\begin{tabular}{|l|l|l|l|l|}
\hline Colagrasso, Fournier, & As part of a mixed & 27 participants & Thematic analysis & 3 themes were identified: participants' appraisal of their \\
Fitzpatrick and Hebert. & methods investigation, & discussed their & of verbal and written & tinnitus, factors modulating tinnitus experience and \\
2018. A qualitative study & & tinnitus through & accounts. & consequences of tinnitus. Attention is considered to have \\
on factors modulating & & semi-structured & & particular importance in regulating tinnitus distress. \\
tinnitus experience ${ }^{35}$ & & interview and & & \\
& & journal entry. & & \\
\hline
\end{tabular}


Three dominant themes were identified: 'losing body ownership', 'living with invisible weakness' (themes originally described by Dauman et al ${ }^{23}$ and 'tinnitus as an embodied experience of distress'.

\section{'Losing body ownership'}

Tinnitus entails a loss of control over auditory perception which impinges on free will, losing the ability to switch off sound and experience quiet at will. Participants refer to 'being invaded by inescapable noise' ${ }^{23}$. Terms such as 'invasion' and 'intrusion' communicate a sense of an external force removing body ownership. Participants describe coping processes by acquiring control over their thoughts about the persistent presence of sound. This was achieved by re-framing the comparison $^{30}$ with other problems and re-evaluating the impact ${ }^{22}$. Understanding tinnitus helps to bring back a sense of ownership ${ }^{30}$ to their experience ${ }^{22}$. Sound therapies have value as exerting control rather than removal of the tinnitus perception ${ }^{32}$. In an autoethnographic account there is a description of fear of this loss of ownership and control over bodily experience ${ }^{31}$. Greenberg and Leigh's participants report similar loss of ownership and autonomy ${ }^{32}$ : 'It's the most awful thing...it just takes over your life'.

The presence of accompanying hearing loss is noted to worsen this loss of body ownership for example a participant reports 'even the most basic things have been spoiled' as communication is compromised ${ }^{33}$. The loss of body ownership is described as 'something that is in control of me'. ${ }^{33}$

\section{'Living with invisible weakness'}

The invisibility of tinnitus makes it a challenge for others to understand ${ }^{34}$. It is an inherently individualised experience ${ }^{22}$ and as such brings a sense of separating individuals from those closest to them. Finding a language to describe the tinnitus is also therefore challenging ${ }^{32}$. There are 
concerns about 'sounding crazy' ${ }^{32}$. The lack of language is also a feature of the clinical encounter. The accounts include complaints about lack of clear information and explanations that would help them interpret the tinnitus ${ }^{33}$.

\section{Tinnitus as an embodied experience of distress}

Descriptions of distress ${ }^{23}$ are interwoven with accounts ${ }^{22}$ about tinnitus ${ }^{33}$. Participants describe restricted social lives, anxieties about the long term consequences of hearing tinnitus and sleep difficulties ${ }^{33}$. This distress is attached to a sense of loss. ${ }^{35}$

Colagrasso et al. ${ }^{35}$ refer to the physical state embodied with tinnitus which can include feeling physically unwell, fatigue and auditory strain. These descriptions are echoed elsewhere. ${ }^{22}$

\section{Contributions from the lifeworld of tinnitus}

These themes highlight the human experience in which tinnitus perception and tinnitus perceiver are one. Important features of life with tinnitus are a sense of loss of body ownership, negotiating the invisibility of this experience and managing psychological distress. In a lifeworld perspective these themes encompass the embodied meaning that tinnitus has. Meanings that extend far beyond content descriptions of the tinnitus perception itself (loudness, pitch etc) to describing a sense of loss of ownership and autonomy (identity). As a result the experience is inherently distressing (mood), in part because of the invisibility of it. Individual lifeworld descriptions are by definition subjective and unique, by examining these patterns of description there are insights and clues about what matters to the people affected by tinnitus. This insight is vital in developing patient centered interventions that respond to the impact of the tinnitus on the lifeworld. The perceiver experience has only been fully realized through interpretivist research approaches. These insights provide new paradigms and models to understand the mechanisms and processes behind tinnitus and associated distress (e.g. thinking processes). ${ }^{22}$ Qualitative research provides insight into the important features of the experience to target clinical interventions. ${ }^{30}$ It leads us to providing tools to inform and share information with people with tinnitus ${ }^{4}$. Qualitative accounts also prioritise the patient voice, bringing the role of the perceiver back, rather than simply focusing on 
the perception ${ }^{32}$, thus enabling emancipation through research. This 'lifeworld turn' opens up opportunities for re-humanizing healthcare ${ }^{13}$, for adjusting care so that it prioritizes the well-being of patients, and for busting the myth of the 'mind-body problem'. This move from object to subject is a crucial shift in redressing the dualist and reductionist dominance in tinnitus research.

\section{Notes}

1.McCormack A, Edmondson-Jones M, Somerset S, Hall D.,2016. A systematic review of the reporting of tinnitus prevalence and severity. Hearing research 2016 Jul; 1;337:70-9.

https://doi.org/10.1016/j.heares.2016.05.009

2.Hoare DJ, Hall DA.,2011. Clinical guidelines and practice: a commentary on the complexity of tinnitus management. Evaluation \& the health professions $2011 \mathrm{Dec} ; 34(4): 413-20$. Doi:

$10.1177 / 0163278710390355$.

3. Department of Health, 2009. Provision of Services for Adults With Tinnitus. A Good Practice Guide. Central Office of Information. London, United Kingdom; 2009.

https://webarchive.nationalarchives.gov.uk/20130124045237/http://www.dh.gov.uk/prod_consum_ dh/groups/dh_digitalassets/documents/digitalasset/dh_093810.pdf

4. Pryce H, Durand MA, Hall A, Shaw R, Culhane BA, Swift S, Straus J, Marks E, Ward M, Chilvers K.,2018. The development of a decision aid for tinnitus. International Journal of Audiology 2018 Jun; 14:1-6. https://doi.org/10.1080/14992027.2018.1468093

5. Soleymani T, Pieton D, Pezeshkian P, Miller P, Gorgulho AA, Pouratian N, De Salles AA.,2011. Surgical approaches to tinnitus treatment: A review and novel approaches. Surgical neurology international. 2011;2. http://surgicalneurologyint.com/surgicalint-articles/surgical-approaches-totinnitus-treatment-a-review-and-novel-approaches/_DOI:10.4103/2152-7806.86834 
6. Wegger M, Ovesen T, Larsen DG., 2017. Acoustic coordinated reset neuromodulation: a systematic review of a novel therapy for tinnitus. Frontiers in neurology. 2017 Feb 13;8:36._doi: 10.3389/fneur.2017.00036.

7. Our impact. 2018. British Tinnitus Association. https://www.tinnitus.org.uk/Handlers/Download.ashx?IDMF=0dcf864d-9d8f-4388-a0b4$\underline{160 a 77 a b f d 2 a}$

8. Pryce H, Hall A, Shaw R, Culhane BA, Swift S, Straus J, Claesen B.,2018. Patient preferences in tinnitus outcomes and treatments: a qualitative study. International Journal of Audiology 2018 Oct 3;57(10):784-90. https://doi.org/10.1080/14992027.2018.1484184

9.Hoare DJ, Kowalkowski VL, Kang S, Hall DA., 2011. Systematic review and meta-analyses of randomized controlled trials examining tinnitus management. The Laryngoscope 2011 Jul;121(7):1555-64._doi: 10.1002/lary.21825

10.Pryce H, Hall A, Marks E, Culhane BA, Swift S, Straus J, Shaw RL.,2018. Shared decisionmaking in tinnitus care-An exploration of clinical encounters. British Journal of Health Psychology. 2018 Mar; 25._doi: 10.1111/bjhp.12308

11.Descriptions in: Woivalin T, Krantz G, Mäntyranta T, Ringsberg KC.,2004. Medically unexplained symptoms: perceptions of physicians in primary health care. Family Practice 2004 Apr; 1;21(2):199-203. https://doi.org/10.1093/fampra/cmh217. And Wainwright D, Calnan M, O'Neil C, Winterbottom A, Watkins C.,2006. When pain in the arm is 'all in the head': the management of medically unexplained suffering in primary care. Health, Risk \& Society. 2006 Mar; 1;8(1):71-88. https://doi.org/10.1080/13698570500532512. Balint M. The doctor, his patient and the illness. London:Churchill Livingstone, 1964.

12. Illustrated in Hoare DJ, Edmondson-Jones M, Gander PE, Hall DA.,2014. Agreement and reliability of tinnitus loudness matching and pitch likeness rating. PLoS One. $2014 \mathrm{Dec}$; 5;9(12):e114553._doi: 10.1371/journal.pone.0114553. and Husain FT, Schmidt SA.,2014. Using resting state functional connectivity to unravel networks of tinnitus. Hearing research 2014 Jan; 1;307:153-62._doi: 10.1016/j.heares.2013.07.010.

13. Explained in Todres L, Galvin K, Holloway I.,2009. The humanization of healthcare: a value framework for qualitative research. International Journal of Qualitative Studies on Heatlh and Wellbeing 2009; 4:2. DOI: 10.1080/17482620802646204. And Todres L, Galvin K, and Dahlberg K.,2014. Caring for insiderness: Phenomenologically informed insights that can guide practice. International Journal of Qualitative Studies on Health and Well-Being $2014 ; 9: 21421$. https://doi.org/10.3402/qhw.v9.21421

14.McKenna L, Marks EM, Hallsworth CA, Schaette R.,2017. Mindfulness-Based Cognitive Therapy as a Treatment for Chronic Tinnitus: A Randomized Controlled Trial. Psychotherapy and psychosomatics 2017;86(6):351-61._doi: 10.1159/000478267.

15. Wade D.,2006. Why physical medicine, physical disability and physical rehabilitation? We should abandon Cartesian dualism. Clinical Rehabilitation 2006 Mar; 20(3): 185-90.

https://doi.org/10.1191/0269215506cr952ed. Salmon P, Humphris GM, Ring A, Davies JC, Dowrick CF.,2006. "Why do primary care physicians propose medical care to patients with medically unexplained symptoms? A new method of sequence analysis to test theories of patient pressure." Psychosomatic Medicine. 2006 Jul; 1;68(4):570-7. https://doi.org/10.1097/01.psy.0000227690.95757.64 
16. Parsons, Talcott., 1991. The social system. Psychology Press, London 1991.

17. Ferrari R, Kwan O.,2001. The no-fault flavor of disability syndromes. Medical hypotheses 2001 Jan; 1;56(1):77-84. https://doi.org/10.1054/mehy.2000.1115

18. Galvin K, and Todres L.2013. Caring and well-being: A lifeworld approach. Routledge, 2013.https://doi.org/10.4324/9780203082898

19. Polkinghorne DE.,2004. Practice and the human sciences: the case for a judgement-based practice of care. Albany, NY. State University Press. 2004.

20.Described in :Ashworth P.,2003. An approach to phenomenological psychology: The contingencies of the lifeworld. Journal of phenomenological psychology. 2003 Nov ;1;34(2):145-56. https://philpapers.org/go.pl?id=ASHAAT\&proxyld=\&u=http\%3A\%2F\%2Fdx.doi.org\%2F10.1163\%2 F156916203322847119. Also Walseth LT, Schei E., 2011. Effecting change through dialogue: Habermas' theory of communicative action as a tool in medical lifestyle interventions. Medicine, Health Care and Philosophy. 2011 Feb; 1;14(1):81-90. DOI:10.1007/s11019-010-9260-5

21. Zelić T.,2008. On the Phenomenology of the Life-World. Synthesis philosophica. 2008 Jan ;1;46:413-26. https://hrcak.srce.hr/37220

22. Pryce H, Chilvers K., 2018.Losing silence, gaining acceptance: a qualitative exploration of the role of thoughts in adult patients with subjective tinnitus. International Journal of Audiology. 2018 Nov; 2;57(11):801-8._doi: 10.1080/14992027.2018.1500041. Thompson P, Pryce H, Refaie E. Group or individual tinnitus therapy: What matters to participants? Audiological Medicine. 2011 Sep ;1;9(3):110-6. https://doi.org/10.3109/1651386X.2011.604470

23. Dauman N, Erlandsson SI, Albarracin D, Dauman R.,2017. Exploring tinnitus-induced disablement by persistent frustration in aging individuals: a grounded theory study. Frontiers in aging neuroscience. 2017 Aug ;10;9:272. https://doi.org/10.3389/fnagi.2017.00272

24. Gendlin ET.,1984. The client's client: The edge of awareness. Client-centered therapy and the person-centered approach New directions in theory, research and practice. 1984; 76-107. Ttp://www.focusing.org/gendlin/docs/gol_2149.html

25. Examples in Beukes EW, Manchaiah V, Davies AS, Allen PM, Baguley DM, Andersson G., 2018. Participants' experiences of an Internet-based cognitive behavioural therapy intervention for tinnitus. International Journal of Audiology. 2018 Dec; 2;57(12):947-54.

https://doi.org/10.1080/14992027.2018.1453171. and in Tuepker A, Elnitsky C, Newell S, Zaugg T, Henry JA.,2018. A qualitative study of implementation and adaptations to Progressive Tinnitus Management (PTM) delivery. PloS one. 2018 May; 16;13(5):e0196105.

https://doi.org/10.1371/journal.pone.0196105

26. Hunter A.,2018. There are more important things to worry about: attitudes and behaviours towards leisure noise and use of hearing protection in young adults. International journal of audiology. 2018 Jun ;3;57(6):449-56. https://doi.org/10.1080/14992027.2018.1430383

27. Erlandsson SI, Eriksson-Mangold M, Wiberg A.,1996. Ménière's disease: trauma, distress and adaptation studied through focus interview analyses. Scandinavian audiology. Supplementum. 1996;43:45-56. https://europepmc.org/abstract/med/8738644 
28. Watts EJ, Fackrell K, Smith S, Sheldrake J, Haider H, Hoare DJ.,2018. Why is tinnitus a problem? A qualitative analysis of problems reported by tinnitus patients. Trends in hearing. 2018 Nov; 22:2331216518812250. https://journals.sagepub.com/doi/pdf/10.1177/2331216518812250

29. Zimmer, L.,2006. Qualitative meta-synthesis: a question of dialoguing with texts. Journal of advanced nursing 2006; 53: 311-318. https://onlinelibrary.wiley.com/doi/pdf/10.1111/1.13652648.2006.03721.x

30.Adams, J., Verrier, E., Walsh, M., \& Lind, C.,2010. Adults' perceptions of their tinnitus and a tinnitus information service. Australian and New Zealand Journal of Audiology.2010; 32, 2, 83-94. http://hdl.handle.net/2328/37080

31. Wheeler S. and Hopwood A.G.,2015. Tinnitus: a Deafhearing phenomenon. Qualitative Inquiry. 2015; 21(2) 173-4 http://imaginativeethnography.org/wp-

content/uploads/2015/04/Qualitative-Inquiry-2015-Wheeler.pdf

32. Greenberg B, Leigh K.,2018. Loss, meaning making, \& reconstruction of narratives in adults enduring tinnitus exacerbated by exposure to sound. The Practitioner Scholar: Journal of Counseling and Professional Psychology 2018 Apr; $11 ; 7$. http://www.thepractitionerscholar.com/article/view/17961/11874

33. Marks E, Smith P, McKenna L.,2019. Living with tinnitus and the health care journey: An interpretative phenomenological analysis. British Journal of Health Psychology 2019 Jan; 4. Doi: 10.1111/bjhp.12351.

34. Andersson G, Edvinsson E.,2008. Mixed feelings about living with tinnitus: A qualitative study. Audiological Medicine. 2008 Jan; 1:48-54. https://doi.org/10.1080/16513860801899355

35.Colagrosso EM, Fournier P, Fitzpatrick EM, Hébert S.,2018. A Qualitative Study on Factors Modulating Tinnitus Experience. Ear and hearing $2018 \mathrm{Jul}$.

https://doi.org/10.1097/AUD.0000000000000642

\section{Bibliography}

Adams, J., Verrier, E., Walsh, M., \& Lind, C. "Adults' perceptions of their tinnitus and a tinnitus information service". Australian and New Zealand Journal of Audiology. 32 (2010): 83-94.

http://hdl.handle.net/2328/37080

Andersson G, Edvinsson E. "Mixed feelings about living with tinnitus: A qualitative study". Audiological Medicine. (2008) Jan; 1:48-54. https://doi.org/10.1080/16513860801899355

Ashworth P. "An approach to phenomenological psychology: The contingencies of the lifeworld." Journal of phenomenological psychology. (2003) Nov ;1;34(2):145-56.

https://philpapers.org/go.pl?id=ASHAAT\&proxyld=\&u=http\%3A\%2F\%2Fdx.doi.org\%2F10.1163\%2 F156916203322847119. 
Beukes EW, Manchaiah V, Davies AS, Allen PM, Baguley DM, Andersson G. "Participants' experiences of an Internet-based cognitive behavioural therapy intervention for tinnitus." International Journal of Audiology. (2018) Dec; 2;57(12):947-54.

https://doi.org/10.1080/14992027.2018.1453171.

British Tinnitus Association. https://www.tinnitus.org.uk/Handlers/Download.ashx?IDMF=0dcf864d9d8f-4388-a0b4-160a77abfd2a

Colagrosso EM, Fournier P, Fitzpatrick EM, Hébert S. "A Qualitative Study on Factors Modulating Tinnitus Experience." Ear and Hearing (2018) Jul 25.

https://doi.org/10.1097/AUD.0000000000000642

Dauman N, Erlandsson SI, Albarracin D, Dauman R. "Exploring tinnitus-induced disablement by persistent frustration in aging individuals: a grounded theory study." Frontiers in aging neuroscience. (2017) Aug ;10;9:272. https://doi.org/10.3389/fnagi.2017.00272

Department of Health. Provision of Services for Adults With Tinnitus. A Good Practice Guide. Central Office of Information. London, United Kingdom; (2009).

https://webarchive.nationalarchives.gov.uk/20130124045237/http://www.dh.gov.uk/prod_consum_ dh/groups/dh_digitalassets/documents/digitalasset/dh_093810.pdf

Ferrari R, Kwan O. "The no-fault flavor of disability syndromes." Medical hypotheses (2001) Jan; 1;56(1):77-84. https://doi.org/10.1054/mehy.2000.1115

Galvin, Kathleen, and Les Todres. Caring and well-being: A lifeworld approach. Routledge, (2013). https://doi.org/10.4324/9780203082898

Greenberg B, Leigh K. "Loss, meaning making, \& reconstruction of narratives in adults enduring tinnitus exacerbated by exposure to sound." The Practitioner Scholar: Journal of Counseling and Professional Psychology (2018) Apr; 11;7.

http://www.thepractitionerscholar.com/article/view/17961/11874

Hoare DJ, Hall DA. "Clinical guidelines and practice: a commentary on the complexity of tinnitus management." Evaluation \& the health professions (2011) Dec; 34(4):413-20. doi:

$10.1177 / 0163278710390355$. 
Hoare DJ, Edmondson-Jones M, Gander PE, Hall DA. "Agreement and reliability of tinnitus loudness matching and pitch likeness rating." PLoS One. (2014) Dec; 5;9(12):e114553._doi: 10.1371/journal.pone.0114553.

Hunter A. "There are more important things to worry about: attitudes and behaviours towards leisure noise and use of hearing protection in young adults." International journal of audiology. (2018) Jun; 3;57(6):449-56. https://doi.org/10.1080/14992027.2018.1430383

Husain FT, Schmidt SA. "Using resting state functional connectivity to unravel networks of tinnitus." Hearing research (2014) Jan; 1;307:153-62._doi: 10.1016/j.heares.2013.07.010.

Marks E, Smith P, McKenna L. "Living with tinnitus and the health care journey: An interpretative phenomenological analysis." British Journal of Health Psychology (2019) Jan; 4. doi: 10.1111/bjhp.12351

McCormack A, Edmondson-Jones M, Somerset S, Hall D. "A systematic review of the reporting of tinnitus prevalence and severity." Hearing research (2016) Jul; 1;337:70-9.

https://doi.org/10.1016/j.heares.2016.05.009

McKenna L, Marks EM, Hallsworth CA, Schaette R. "Mindfulness-Based Cognitive Therapy as a Treatment for Chronic Tinnitus: A Randomized Controlled Trial." Psychotherapy and psychosomatics (2017);86(6):351-61._doi: 10.1159/000478267.

Polkinghorne DE. Practice and the human sciences: the case for a judgement-based practice of care. Albany, NY. State University Press. 2004.

Pryce H, Durand MA, Hall A, Shaw R, Culhane BA, Swift S, Straus J, Marks E, Ward M, Chilvers K. "The development of a decision aid for tinnitus". International Journal of Audiology (2018) Jun; 14:1-6. https://doi.org/10.1080/14992027.2018.1468093

Pryce $\mathrm{H}$, Chilvers K. "Losing silence, gaining acceptance: a qualitative exploration of the role of thoughts in adult patients with subjective tinnitus." International Journal of Audiology. (2018) Nov; 2;57(11):801-8._doi: 10.1080/14992027.2018.1500041.

Salmon P, Humphris GM, Ring A, Davies JC, Dowrick CF. "Why do primary care physicians propose medical care to patients with medically unexplained symptoms? A new method of 
sequence analysis to test theories of patient pressure." Psychosomatic Medicine. (2006) Jul; 1;68(4):570-7. https://doi.org/10.1097/01.psy.0000227690.95757.64

Soleymani T, Pieton D, Pezeshkian P, Miller P, Gorgulho AA, Pouratian N, De Salles AA. "Surgical approaches to tinnitus treatment: A review and novel approaches." Surgical neurology international. (2011) ;2. http://surgicalneurologyint.com/surgicalint-articles/surgical-approaches-totinnitus-treatment-a-review-and-novel-approaches/_DOI:10.4103/2152-7806.86834

Todres L, Galvin K, Holloway I. "The humanization of healthcare: a value framework for qualitative research". International Journal of Qualitative Studies on Health and Well-being (2009); 4:2. DOI: $10.1080 / 17482620802646204$.

Todres, Les, Kathleen T. Galvin, and Karin Dahlberg. "Caring for insiderness: Phenomenologically informed insights that can guide practice." International Journal of Qualitative Studies on Health and Well-Being (2014);9 : 21421. https://doi.org/10.3402/qhw.v9.21421

Thompson P, Pryce H, Refaie E. "Group or individual tinnitus therapy: What matters to participants?" Audiological Medicine. (2011) Sep ;1;9(3):110-6.

https://doi.org/10.3109/1651386X.2011.604470

Tuepker A, Elnitsky C, Newell S, Zaugg T, Henry JA. "A qualitative study of implementation and adaptations to Progressive Tinnitus Management (PTM) delivery". PloS one. (2018) May; 16;13(5):e0196105. https://doi.org/10.1371/journal.pone.0196105

Walseth LT, Schei E. "Effecting change through dialogue: Habermas' theory of communicative action as a tool in medical lifestyle interventions". Medicine, Health Care and Philosophy. (2011) Feb; 1;14(1):81-90. DOI:10.1007/s11019-010-9260-5

Watts EJ, Fackrell K, Smith S, Sheldrake J, Haider H, Hoare DJ. "Why is tinnitus a problem? A qualitative analysis of problems reported by tinnitus patients." Trends in hearing. (2018) Nov; 22:2331216518812250. https://journals.sagepub.com/doi/pdf/10.1177/2331216518812250

Wheeler S. and Hopwood A.G. "Tinnitus: a Deafhearing phenomenon.” Qualitative Inquiry. (2015); 21 (2) 173-4 http://imaginativeethnography.org/wp-content/uploads/2015/04/Qualitative-Inquiry2015-Wheeler.pdf 
Wegger M, Ovesen T, Larsen DG. "Acoustic coordinated reset neuromodulation: a systematic review of a novel therapy for tinnitus." Frontiers in neurology. (2017) Feb 13;8:36._doi:

10.3389/fneur.2017.00036.

Zimmer, Lela. "Qualitative meta-synthesis: a question of dialoguing with texts." Journal of advanced nursing (2006); 53: 311-318. https://onlinelibrary.wiley.com/doi/pdf/10.1111/j.13652648.2006.03721.x 